\title{
Effects of Charcoal-Treated Porcine Follicular Fluid on Ovulation in Rabbits
}

\author{
Yasunori Yoshida, Nobuhiro ŌHara, Tokie SAmorI, \\ Teruo Maeda, Takato Terada and Yoshio Tsutsumi \\ Animal Reproduction Laboratory, Faculty of Applied Biological \\ Science, Hiroshima University, Fukuyama-shi 720
}

(Received April 5, 1985)

\begin{abstract}
Effects of charcoal-treated porcine follicular fluid (CTPFF) on ovulation in rabbits were examined. Sixty-one does were divided into 4 groups. Group 1 showed that an intravenous injection of 15 IU human chorionic gonadotropin (hCG) gave rise to ovulation in all 4 does either treated with CTPFF or control. Does in group 2 received $4 \mathrm{ml}$ of whole PFF (WPFF) or CTPFF once daily for 10 days, followed by 5 IU hCG. With WPFF administration, 1 out of 4 does ovulated, while 3 out of 4 does ovulated in the CTPFF and control groups. A mild aplasia of corpora lutea was noted in does which received CTPFF. In group 3,10 administrations of CTPFF were made at successive 12-hour intervals followed by $10 \mathrm{IU}$ hCG at the final injection of CTPFF; 3 out of 6 does ovulated ( 6 out of 8 does in control group). The number of ovulations was significantly lower in the CTPFF group than in controls. Laparotomy 4 days after hCG treatment showed that the number of large follicles was smaller in ovaries of nonovulated does in the treated group than in controls. Size and coloration of vulvas decreased 2 days after the beginning of treatments. In group 4 , effects of CTPFF administration 3 times and 2 times per day were compared. Each doe was mated only 3 times of copulations without hCG. No ovulations occurred in both CTPFF-treated groups, though does ovulated were 2 out of 10 in 3 times saline-treated controls and 2 out of 6 in 2 times saline-treated control groups. Macroscopic measurements of follicles in non-ovulated does, and appearance of vulvar swelling and coloration showed similar trends with group 3 . These result suggest that follicle-stimulating hormone suppressive activities in CTPFF will suppress follicular development in rabbit ovaries (relating low ovulation rate) and this causes a decrease of estrogen levels in blood, leading the fading and/or withering of vulvas.

Jpn. J. Zootech. Sci., 56 (12): 971-979, 1985
\end{abstract}

Key words: Follicular fluid, inhibin, ovulation, rabbit reproduction, vulvar coloration

According to El-SheikH and Nalbandov' ${ }^{1}$, there was no significant difference in numbers of corpora lutea between bred does injected with porcine follicular fluid (PFF) preparation and control does, though the number of implantation sites and living fetuses decreased significantly by day 16 . Immunized rabbits with inhibin preparations extracted from human or bovine seminal fuids and ram-rete testis fluid showed higher follicle-stimulating hormone (FSH) levels than nonimmunized does $^{2}$. Male castrated rabbits showed a marked reduction in FSH levels within 4-5 hours after the beginning of perfusion of an active inhibin fraction of ram-rete testis fluid for 6 hours $^{2}$. MILls and CoPLAND ${ }^{3)}$ demonstrated in rabbits that intraperitoneal injections of charcoal-treated porcine follicular fuid (CTPFF) at 6,12 and 18 hours 
post coitum (p.c.) completely blocked the second FSH surge, which was delayed until 60 hours p.c., and that FSH levels at 60 hours p.c. were nearly 3 times greater than those measured at 24 hours $p . c$. in the second FSH surge. According to Ramasharma and SAIRAM ${ }^{4}$, an intravenous administration of fraction $\mathrm{J}$ derived from human seminal plasma caused a progressive reduction in circulating FSH levels in intact male rabbits, with a maximum effect reached at about 4 hours. In cases of castrated male and female rabbits, CTPFF given twice a day for 4 days following castration clearly suppressed serum FSH levels during the days of administration, while a significant increase in FSH and $\mathrm{LH}$ was evident within 24 hours following castration in the controls $^{5}$. Furthermore, inhibition of FSH release in cultured rabbit pituitary cells by CTPFF was dose-dependent, as in cultured rat pituitary cells ${ }^{8}$.

These above-mentioned facts suggest that rabbit pituitary cells respond to inhibin or to FF. The present study deals with the inhibiting effects of porcine follicular fluid on follicular development and ovulation in the rabbit, known as the reflex ovulation.

\section{Materials and Methods}

Animals Sixty-one virgin, female, adult Japanese White rabbits, weighing 2.8$4.3 \mathrm{~kg}$, were used. All of the animals were reared in individual cages for over one month after purchase from a local commercial rabbit breeder, with food and water provided ad libitum. They were divided into 4 groups: 2 does for treatment and the other 2 does as controls in group $1 ; 4$ does for treatment a, 4 for treatment b and 4 as controls in group $2 ; 6$ for treatment and 8 as controls in group 3; and 10 for treatment a, 5 for treatment $b, 10$ as control a and 6 as control b in group 4 (Table 1). Porcine follicular fluid (PFF) Porcine ovaries were collected at a local meat-packing center, immediately placed on ice and transported to our laboratory. Follicular fluid was aspirated mainly from small and medium follicles, excluding ovaries having corpora lutea or cystic follicles. The fluid was pooled in a plastic bottle and stored at $-20^{\circ} \mathrm{C}$ until use. Before use, the frozen PFF was slowly melted in a refrigerator at $4^{\circ} \mathrm{C}$. Most of the fluid was treated with charcoal $(5 \mathrm{~g} / 100 \mathrm{ml})$ to remove steroids, stirred for 24 hours at $4^{\circ} \mathrm{C}$, and centrifuged at $1,650 \mathrm{~g}$ for $30 \mathrm{~min}$. The supernatant was recentrifuged at $24,000 \mathrm{~g}$ for $60 \mathrm{~min}$ to further remove charcoal and cellular contaminants, and this procedure was repeated once more, followed by two filtrations with $0.45 \mu \mathrm{m}$ (MILLEX-HA) and $0.22 \mu \mathrm{m}$ (MILLEX-GV) millipore filters (result : charcoal-treated porcine follicular fluid, CTPFF). A small amount of PFF was processed similarly except for the charcoal treatment (result: WPFF). Both of the filtrates were used for injection. As control fluid for injection, porcine serum (PS) was used in group 1; but in all other groups sterile physiological saline was used because inhibin activities have been found in blood ${ }^{7-10)}$.

Injection schedule and methods of observations In group 1, 3 or $2 \mathrm{~m} l$ of CTPFF was injected subcutaneously or intravenously for 10 days once a day, and 15 IU human chorionic gonadotropin ( $\mathrm{hCG}$ ) was injected intravenously into the marginal vein of the ear simultaneously with a final injection of PFF. Porcine serum was injected simi- 
larly in the control group (Table 1). Does were laparotomized after 3 (subcutaneously injected does) or 2 days (intravenously injected does) to examine ovaries macroscopically for the number of corpora lutea.

In group 2, $4 \mathrm{ml}$ of WPFF (2-a) or CTPFF (2-b) was subcutaneously injected once a day for 10 days, followed by an intravenous injection of 5 IU hCG simultaneously with the final injection of PFF. Seven days after administration of hCG, the does' ovaries were inspected by laparotomy.

In group 3, after 10 subcutaneous injections of $4 \mathrm{ml}$ CTPFF at 12-hour intervals for 4.5 days, $10 \mathrm{IU}$ hCG was administered i.v. with the final injection of CTPFF. Ninety-six hours after hCG administration, laparotomy was performed to count corpora lutea in both ovaries of ovulatory does and to measure macroscopically the diameter of visible ovarian follicles in non-ovulatory does. In does of this group, the appearance of the vulva was inspected once a day at midday, from one day before injection of CTPFF to one day before laparotomy. The appearance of the vulva was scored 1 (non-swollen, small and whitish vulva) to 4 (largely swollen, congested, and purple or dark red vulva) by the degree of vulvar swelling and coloration for statistical analysis between groups.

In group 4-a, $5 \mathrm{ml}$ CTPFF was subcutaneously given 15 times at 8-hour intervals ( 4 and $2 / 3$ days) in each doe. The does were restrained in buck's hutches by hand ${ }^{11}$ ) to allow 3 matings immediately after the final injection of PFF, and no hCG was given. In group $4-\mathrm{b}, 4 \mathrm{~m} l \mathrm{CTPFF}$ was given 10 times at 12 -hour intervals and does were mated as in group 4-a. The does were laparotomized at 96 hours after mating and their ovaries were observed. In ovulated does, reproductive tracts were removed and flushed with physiological saline to examine embryos. Appearance of the vulva was noted as in group 3, also.

Statistical analysis The effects of WPFF and CTPFF on numbers of ovulations, numbers of unovulated follicles and appearances of vulvas were analyzed using Student's $t$ test.

\section{Results}

Administration of $15 \mathrm{IU}$ hCG (group 1) caused ovulation in all does, and no differences between treatment with PFF and treatment with porcine serum were found in the number of ovulations, regardless of the injection method (Table 1). Therefore, after subcutaneous injection of CTPFF or saline, the dosage of hCG was decreased in groups 2 (5 IU) and $3(10 \mathrm{IU})$, and only copulatory stimulus was given in group 4 without hCG treatment.

After WPFF was given, only 1 out of 4 animals ovulated by 5 IU hCG in group $2-\mathrm{a}$, while 3 out of 4 does ovulated both in group $2-\mathrm{b}$ and in control. Ovulated does in this group showed no differences in number of ovulations. It was noted, however, that corpora lutea of the does treated with CTPFF showed conic projections suggesting mild aplasia (2-b), while corpora lutea in the WPFF and saline-injected groups appeared quite normal, showing a full, round projection. 
In group 3 (10 IU hCG), rates of does ovulated in the CTPFF group were $50 \%$ (3/6) with a smaller number of ovulations compared to those of controls $(P<0,01)$, in which 6 does of $8(75 \%)$ ovulated. Population of follicles (excluding hemorrhagic follicles) in PFF treated does showed no significant difference to that of control ani-

Table 1. Effects of administrations of porcine follicular fluid, porcine serum or saline to female rabbits on ovulations induced by human chorionic gonadotropin (hCG) or by mating with bucks

\begin{tabular}{|c|c|c|c|c|c|c|c|c|}
\hline \multirow{2}{*}{ Group } & \multirow{2}{*}{ Treatment } & \multicolumn{4}{|c|}{ Dose } & \multirow{2}{*}{$\begin{array}{r}\mathrm{hCG} \\
(\mathrm{IU})\end{array}$} & \multirow{2}{*}{$\begin{array}{l}\text { No. of does ovulated } \\
\text { vs. } \\
\text { No. of does treated }\end{array}$} & \multirow{2}{*}{$\frac{\text { No. of ovulations }}{\text { Mean }}$} \\
\hline & & $(\mathrm{m} l)$ & $\times(t$ & imes) & (days) & & & \\
\hline \multirow{4}{*}{1} & CTPFF & 3 & $x$ & 10 & 10 & 15 & $1: 1$ & $(7)$ \\
\hline & \multirow{3}{*}{ PS } & 02 & $x$ & 10 & 10 & 15 & $1: 1$ & (10) \\
\hline & & 3 & $x$ & 10 & 10 & 15 & $1: 1$ & (9) \\
\hline & & $O 2$ & $\times$ & 10 & 10 & 15 & $1: 1$ & (9) \\
\hline $2-\mathbf{a}$ & WPFF & 4 & $x$ & 10 & 10 & 5 & $1: 4$ & (6) \\
\hline \multirow[t]{2}{*}{$2-b$} & CTPFF & 4 & $x$ & 10 & 10 & 5 & $3: 4$ & $6.3(5,4,8)^{11}$ \\
\hline & $\mathrm{S}$ & 4 & $x$ & 10 & 10 & 5 & $3: 4$ & $6.0(10,5,3)$ \\
\hline \multirow{2}{*}{3} & CTPFF & 4 & $x$ & 10 & $4^{1 / 2}$ & 10 & $3: 6$ & $1.7 * *(1,2,2)$ \\
\hline & $\mathrm{S}$ & 4 & $x$ & 10 & $4^{1} / 2$ & 10 & $6: 8$ & $7.5(5,6,8,8,6,12)$ \\
\hline \multirow[t]{2}{*}{$4-a$} & CTPFF & 5 & $x$ & 15 & $4^{2} / 8$ & 0 & $0: 10$ & 0 \\
\hline & $\mathrm{S}$ & 5 & $x$ & 15 & $4^{2} / 3$ & 0 & $2: 10$ & $9.5(12,7)^{2)}$ \\
\hline \multirow[t]{2}{*}{$4 \cdots \mathrm{b}$} & CTPFF & 4 & $x$ & 10 & $41 / 4$ & 0 & $0: 5$ & $\mathrm{O}^{31}$ \\
\hline & $\mathrm{S}$ & 4 & $x$ & 10 & $4^{1 / 2}$ & 0 & $2: 6$ & $10.5(10,11)^{4}$ \\
\hline
\end{tabular}

Note: All does were subcutaneously injected, except 2 does $(O)$ injected i. v. in group 1. WPFF, whole porcine follicular fluid; CTPFF, charcoal-treated porcine follicular fluid; PS, porcine serum; $\mathrm{S}$, physiological saline; $* * P<0.01$. 1) A mild aplasia of corpora lutea was noted. 2) Many blood follicles appeared in ovaries of 4 does. ") Many blood follicles appeared in ovaries of 1 doe. 4) Many blood follicles appeared in ovaries of 1 doe.

Table 2. Numbers of follicles (mean \pm S. D.) of different sizes in non-ovulated does of groups 3 and 4 , observed 4 days after charcoal-treated porcine follicular fluid (CTPFF) treatment.

\begin{tabular}{clcccc}
\hline \multirow{2}{*}{ Group } & Treatment & \multicolumn{4}{c}{ Diameter of follicles (mm) } \\
\cline { 3 - 6 } & & 1.0 & 1.5 & 2.0 & $\geq 2.5$ \\
\hline \multirow{2}{*}{3} & CTPFF & $5.2 \pm 4.3$ & $2.8 \pm 2.9$ & $0.2 \pm 0.4$ & 0 \\
& Saline & $3.0 \pm 3.0$ & $4.7 \pm 3.1$ & $0.7 \pm 1.2$ & 0 \\
$4-\mathrm{a}$ & CTPFF & $6.5 \pm 3.6$ & $1.4 \pm 2.6$ & $0.2 \pm 0.7^{* *}$ & $0.2 \pm 0.9$ \\
& Saline & $3.9 \pm 3.2$ & $3.2 \pm 3.8$ & $2.3 \pm 2.0$ & $0.5 \pm 1.2$ \\
$4-\mathrm{b}$ & CTPFF & $5.5 \pm 2.5$ & $1.5 \pm 2.8$ & 0 & 0 \\
& Saline & $5.0 \pm 5.5$ & $3.1 \pm 2.4$ & $1.6 \pm 1.9$ & 0 \\
$4-(\mathrm{a}+\mathrm{b})$ & CTPFF & $6.1 \pm 3.3$ & $1.4 \pm 2.7^{*}$ & $0.1 \pm 0.5^{* *}$ & $0.1 \pm 0.7$ \\
& Saline & $4.3 \pm 4.0$ & $3.2 \pm 3.4$ & $2.0 \pm 1.9$ & $0.3 \pm 1.0$ \\
\hline
\end{tabular}




\section{Inhibition of Ovulation by Follicular Fluid}

mals as shown in Table 2. It was difficult to count the number of follicles smalle: than $1 \mathrm{~mm}$ with the naked eye. The vulvar swelling and color decreased and faded sharply after PFF treatments, and significant differences from control does were noted 2 to 5 days after CTPFF injection, followed by recovery after the final PFF administra-
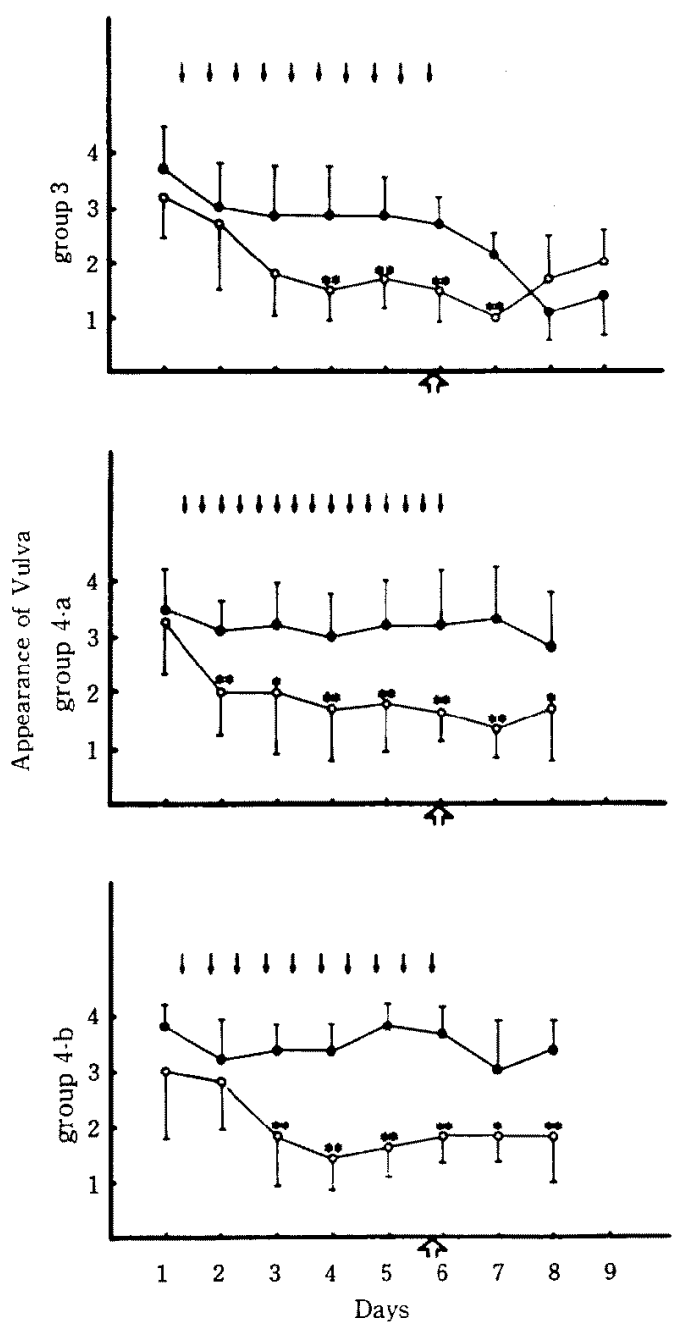

Fig. 1. The effects of administration of charcoal-treated porcine follicular fluid (CTPFF, meantS. D., o) to 6 does of group $3\left(4 \mathrm{ml}\right.$ at 12 -hour intervals for $4 \frac{1 / 2}{\text { days }),} 10$ does of group $4-\mathrm{a}\left(5 \mathrm{ml}\right.$ at 8 -hour intervals for $4 \frac{2 / 3}{3}$ days) and 5 does of group $4-\mathrm{b}\left(4 \mathrm{ml}\right.$ at 12-hour intervals for $4 \frac{1}{2}$ days) on the appeatance of the vulva, in comparison with that of 8 (group 3), 10 (group 4-a) and 6 (group 4-b) does given physiological saline (mean \pm S. D., -$)$ in the same manner of each group, respectively. The criteria for scoring of the appearance of the vulva are given in the text. $\downarrow$, does of CTPFF or $\mathrm{S}$; $\hat{\mathrm{s}}, 10 \mathrm{IU} \mathrm{hCG}$ administration or mating; ${ }^{*} P<0.05$; ** $P<0.01$. 
tion (Fig. 1).

In group 4 (no hCG administered), no ovulation was attained by three copulations with bucks in both of the CTPFF groups (4-a and 4-b). However, the percent of ovulated does was $20 \%(2 / 10)$ in controls treated with $5 \mathrm{ml}$ saline three times a day and $33 \%(2 / 6)$ in controls treated with $4 \mathrm{ml}$ saline twice a day. Furthermore, many blood follicles were found in ovaries of 6 non-ovulated does, including 5 does treated with saline and another doe treated with $4 \mathrm{ml}$ PFF twice a day. Follicular size in non-ovulated ovaries showed a similar tendency in group 3 ; that is, the number of follicles of larger size (more than $1.5 \mathrm{~mm}$ in diameter) was smaller in both treatment groups than in control groups. If data for both treatment groups are combined, significant differences appear between treated and control groups in numbers of 1.5-mm and 2.0-mm follicles (Table 2). The swelling and color of vulva were significantly decreased from one day after CTPFF injection in 4-a and 2 days after in 4-b (Fig, 1). The evaluations of vulvar state in ovulated does at the time of copulation were 4 in 3 does ( 1 doe in $4-\mathrm{a}$ and 2 in $4-\mathrm{b}$ ) and 3 in 1 doe (4-a).

\section{Discussion}

Complete ovulation was demonstrated with 15 IU hCG in group 1, and no difference was noticed in numbers of ovulatory does between 5 or $10 \mathrm{IU}$ hCG dosage (groups 2 and 3, respectively) in CTPFF groups and in control groups. When WPFF was given, only one does out of 4 ovulated, though number of ovulations was similar to controls. Although ovulation was not inhibited following treatment with either steroid-free or protein-denatured bovine FF to nulliparous Holstein heifers given prostaglandin $F_{2 \alpha}$ to cause luteal regression, treatment with whole FF significantly lengthened the interval from prostaglandin $\mathrm{F}_{2 \alpha}$ administration to ovulation (MILLER et al. ${ }^{12}$. The ovulation-inhibiting activity demonstrated in bovine FF is probably due to a combined effects of protein and steroids in FF. Ovulation-inhibiting activity was also demonstrated in steroid-free FF for rats $^{13)}$, hamsters ${ }^{14)}$ and rhesus monkeys ${ }^{15)}$, and serum FSH-suppressive activity in PFF acted additively with estradiol in mice ${ }^{16}$. It is well-known that ovulation does not always follow coitus in rabbits ${ }^{17,18}$. In the present study, only 4 out of 16 control does in group 4 ovulated following copulatory stimulus. This figure seems to be rather reasonable because the experiment was, perhaps unfortunately, performed in the hottest season of the year for our area.

For usual rabbit-breeding experiments, an intravenous injection of 20 to 25 IU hCG came to be used very commonly. However, in the present study, a suppressive effect of CTPFF on ovulation appeared at the lower dosages of hCG and in the case of normal coitus without hCG.

Blood follicles have been demonstrated sometimes in ovaries of normal does without copulation $^{11}$, and are very common in ovaries which have received ovulatory stimulation $^{19)}$. However, no precise elucidation has been given on the occurrence of blood follicles in rabbits. In the present study, 5 control does and one treated doe out of 16 in group 4 gave rise to large numbers of blood follicles in their ovaries. We cannot 
give any exact explanation for this; however it appears that copulatory stimuli may have induced this phenomenon. When ovulation was blocked by indomethacin, ovaries were characterized by large hemorrhagic follicles ${ }^{20)}$. Thus, indomethacin must be acting at the ovarian level to interfere with the physical process of ovulation, and not by inhibiting the release of $\mathrm{LH}$ from the pituitary. Therefore, it is speculated that the blood follicles in group 4 may be caused by release of gonadotropin from the pituitary.

Channing et al. ${ }^{15.21)}$ have demonstrated that PFF treatment to 4 intact cycling rhesus monkeys early in the menstrual cycle led to aberrant development of the dominant follicle, as evidenced by a reduction in size and number of granulosa cells recovered from this follicle near midcycle, probably due to the decrease of FSH levels in the plasma. In their additional experiments, 4 monkeys which received two to four daily doses of $4 \mathrm{ml}$ PFF during the anticipated time of the midcycle gonadotropin surges failed to ovulate in the treated cycle, but did ovulate during the next menstrual cycle. Atter 8 days of whole BFF treatment in ewes, also, significant inhibition of follicular growth was noted by MrLer et al. ${ }^{22)}$ Research on the possible dependence of peripheral FSH levels on a nonsteroidal factor in BFF showed that the ovarian inhibin-like factor mediated control of FSH, which regulated the number of follicles maturing in rats ${ }^{23)}$ and hamsters ${ }^{14)}$. Similarly, a recruitment of follicles derived from the secondary FSH surge was suppressed by administration of CTPFF late in proestrus in rats $^{24)}$. According to SASAMOTO et al. ${ }^{25)}$, delay of the selective surge of FSH by CTBFF during the period of ovulation induced by hCG in diestrous rats may induce a retardation of the initiation of follicular maturation or the selection of growing follicles for the succeeding estrous cycle. Administration of a highly purified preparation of human FF inhibin in immature female rats caused marked degenerative changes in the granulosa cells and limited the number of growing follicles ${ }^{26}$. HIRSHFIELD and DE PAOLO ${ }^{27)}$ reported that large follicles were absent in ovaries of all CTPFF-treated rats at estrus, also.

In the present study, follicular development was suppressed by the administration of CTPFF. This may confirm that FSH-suppressive activities in CTPFF are associated with recruitment of follicles in the rabbit, also. Suppression of follicular development may induce a decrease in estrogen secretion from follicles and cause the fading of vulvar color within 1 or 2 days after injection of CTPFF. Although estrus is not sharply demarcated and vulvar appearance is not always an accurate indicator of the desire to copulate, the only external sign of estrus is still congestion and coloration of the vulva, which depend on the presence of follicles above a certain size ${ }^{28.29}$; and the vulvar state may correlate with sexual activity ${ }^{30}$.

\section{Acknowledgments}

We are especially grateful to Prof. W. J. Mellen, Department of Veterinary and Animal Sciences, University of Massachusetts, Amherst, Massachusetts, U.S.A., for kind reviewing of the manuscript. We also appreciate Teikokuzōki Co., Ltd., Japan, 
for supplying gonadotropin and Miyoshi Meat Packing Center, Hiroshima Prefecture, Japan, for collection of porcine ovaries. This work was supported in part by a Grant-in-Aid for Co-operative Research (no. 59360035) from the Ministry of Education, Science and Culture of Japan.

\section{References}

1) El-Sheikh, A. S. and A. V. Nalbandov, Biol. Reprod., 7: 128, Abstr. 82. 1972.

2) Franchimont, P., J. Verstraelen-Proyard, M. T. Hazee-Hagelstein, Ch. Renard, A. Demoulin, J. P. Bourguignon and J. Hustin, Vitamins and Hormones, 37: 243-302. 1979.

3) Mills, T. M. and J. A. Copland, in Program of the Annual Meeting of the Society for the Study of Reproduction. 15th. Madison, Wisconsin. 154. Abstr. 236. 1982.

4) Ramasharma, K. and M. R. Sairam, in The Cell Biology of the Testis. (Bardin, C. W. and R. J. Sherins, eds. ) 307-328. New York Academy of Sciences, New York. 1982.

5) Laborde, N.P., V. Rettori and R. H. Asch, Life Sci., 34: 555-560. 1984.

6) Goodman, A. L., Am. J. Physiol., 246: E 243-E 248. 1984.

7) DePaolo, L. V., D. Shander, P. M. Wise, C. A. Barraclough and C. P. Channing, Endocrinology, 105: 647-654. 1979.

8) Sheth, A. R., A. Y. Vaze, A. N. Thakur, N. J. Arbatti, K. Hazari, S. Mehta and J. Joshi, Indian J. Med. Res., 74: 848-851. 1981.

9) Lee, V. W. K., J. McMaster, H. Quigg, J. Findlay and L. Leversha, Endocrinology, 108: 2403-2405. 1981.

10) Lee, V.W. K., J. McMaster, H. Quigg and L. Leversha, Endocrinology, 111: 1849-1854. 1982.

11) Templeton, G. S., Wildlife Circ., 4: 1-13. 1940.

12) Miller, K.F., S.K. Critser and O.J. Ginther, in Ovarian Follicular and Corpus Luteum Function. (Channing, C. P., J. Marsh and W. A. Sadler, eds.) 417-421. Plenum Press, New York. 1979.

13) Phillips, A., D. W. Hahn and C. P. Channing, Contraception, 26: 617-624. 1982.

14) Chappel, S. C. and F. Selker, Biol. Reprod, 21: 347-352. 1979.

15) Channing, C. P., L. D. Anderson, D. J. Hoover, P. Gagliano and G. Hodgen, Biol. Reprod., 25: 885-903, 1981.

16) Bronson, F. H. and C. P. Channing, Endocrinology, 103: 1894-1898. 1978.

17) Brooks, C. MCC., Am. J. Physiol., 120: 544-553. 1937.

18) Eckstein, P. and S. Zuckerman, in Marshall's Physiology of Reproduction. Vol. 1: Part One. (PARkEs, A. S. ed.) 226-396. Longmans, London. 1962.

19) Harper, M. J. K., J. Endocr., 26: 307-316. 1963.

20) O’Grady, J.P., B. V. Caldwell, F. J. Auletta and L. Sererff, Prostaglandins, 1: 97-106. 1972.

21) Channing, C. P., L. D. Anderson and G. D. Hodgen, in Ovarian Follicular and Corpus Luteum Function. (Channing, C. P., J. Marsh and W. A. Sadler, eds.) 407-415. Plenum Press, New York. 1979.

22) Miller, K.F., J.K. Critser, R. F. Rowe and O. J. Ginther, Biol. Reprod,, 21: 537-544. 1979.

23) Welschen, R., W. P. Hermans and F. H. De Jong, J. Reprod. Fert., 60: 485-493. 1980.

24) Hoak, D. C. and N. B. Schwartz, Proc. Natl. Acad. Sci. USA, 77: 4953-4956. 1980.

25) Sasamoto, S., T. Otani and M. Shirota, J. Endocr., 89: 205-212, 1981.

26) Chari, S., G. Aumüller, E. Daume, G. Sturm and C. Hopkinson, Arch. Gynecol., 230 : 239-249. 1981.

27) Hirshaielo, A. N, and L. V. De Paolo, J. Endocr., 88: 67-71. 1981.

28) Young, W. C., Quart. Rev. Biol., 16: 135-156. 1941.

29) Lefère, B. and M. Caillot, Ann. Biol. anim. Bioch. Biophys,, 18: 1435-1441. 1978.

30) Carlyle, A. and T. D. Williams, J. Physiol, 157: 43 p-44 p. 1961. 


\title{
家鬼の誘起排卵に及ほすす活性炭処理豚卵胞液の影響
}

\author{
吉田康則・大原伸宏・佐守登喜恵 \\ 前田照夫・寺用隆登・堤 義雄 \\ 庆島大学牛:物牛産学部，福山析 720
}

\begin{abstract}
ステロイド除去豚㽗胞液（CTPFF）を崔家鬼に投与 し，それが hCG 注射，または交尾刺激に上る誘起排卵 に及ぼす影響を検剖した。
\end{abstract}

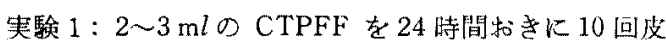
下又は静脈内注射啳， hCG 15 IU 投与で，処理区と対照 区（豚血清投与）の全個体が排䛇した。実験 2：無処理 卵胞液，CTPFF，または生理的食塩液 (S) $94 \mathrm{ml}$ を同 様に 10 日間皮下注射後, $5 \mathrm{IU} の \mathrm{hCG}$ 投与で排期個体 数の割合がそれそれ $1 / 4 ， 3 / 4 ， 3 / 4$ となった。

㬰験 $3:$ CTPFF $4 \mathrm{ml}$ を 12 時間おきに 10 回投与後, $10 \mathrm{IU}$ の hCG 静注で, 処理区 $3 / 6$ ，対照区（S投与）6/8 の個体が排卵し，排卵数は処理区で有意に減少した。実
験 4: a【はCTPFF $5 \mathrm{ml}$ を 8 時間括きに 15 回，b区は $4 \mathrm{ml}$ を 12 時間扣きに 10 回投与後，父尾させた，它の結 果処理区は排䀦ず，対照区（S投与）はa区 $2 / 10 ， b$ 区2/6が排卵した。 また実験 $3 ， 4$ 其に爸理釉了後4日 の観察で大型则胞数の減少傾向が認められた，更に実 験 3 と4で外陰部の状態を経日的に観察したとこる, CTPFF 投与開始後 $1 \sim 2$ 日には腫脹・潮紅の程度が急 に弱まるのが認められた。

以上の結果加 質は家压の卵胞発達を抑制し，排躬率の低下をるたらす と思考される。

日畜会報，56(12)：971-979，1985 